\title{
MULTICRITERIA ANALYSIS OF FLOOD CAUSES IN KUALA LUMPUR
}

\author{
Nur Fazzillah Muhamed Noordin ${ }^{1}$ \\ Project Executive, \\ GEOINFO SERVICES SDN BHD
}

\author{
Alias Abdullah ${ }^{2}$ \& Muhammad Nur Azraei Shahbudin ${ }^{3}$ \\ INTERNATIONAL ISLAMIC UNIVERSITY MALAYSIA
}

\begin{abstract}
In today's world, natural disasters are becoming frequent occurrence as a result of human's excess and waste in using resources, especially land. Its effects can be seen in disasters such as flood in urban areas where population and built-up area is dense. Many studies have been conducted in flood prediction and river management but very few concentrate on evaluation of flood occurrence factors at rivers in urban areas. This study evaluates the significance of factors that cause urban flash floods in Kuala Lumpur by using Multi-Criteria Analysis (MCA) method with special reference to DEFINITE software. This study carries out a systematic approach encompassing a selection of criteria that determines the root cause of flood through consultation with major stakeholders like Department of Irrigation and Drainage (DID), Department of Environment (DOE), Kuala Lumpur City Hall (DBKL), and Malaysian Meteorological Department (MMD). Less than obvious results are due to the complexity and reality of the problem based on the interview of stakeholders with different views on the local environment. The MCA results reveal that stream and land (land use) are the main causes of flooding in urban areas that can be solved with a proper physical planning.
\end{abstract}

Keywords: MCDA, Flood Disasters, Risk Management, Urbanisation, Environment

\footnotetext{
${ }^{1}$ She received a Bachelor Degree of Urban and Regional Planning from International Islamic University Malaysia (fazzillah@geoinfo.com.my).

${ }^{2}$ Professor, Department of Urban and Regional Planning, Kulliyyah of Architecture and Environmental Design, International Islamic University Malaysia, Kuala Lumpur (dralias@iiu.edu.my).

${ }^{3}$ Research Officer, IIUM Consultancies, International Islamic University Malaysia, Kuala Lumpur (azraeishahbudin@gmail.com).
} 


\section{INTRODUCTION}

In 1998 Yangtze's worst flood in 44 years occurred due to deforestation and intensive land development (Brown and Halweil, 1998) whilst in 2004, Bangladesh 10-year cycle floods arrived early also due to deforestation and irrigation (Logan, 2004). However, the 1995 flood in the Netherlands was due to melt water from mountains and extremely heavy rainfall ${ }^{4}$ and the 2002 flood in Germany was due to dam burst (BBC News, $15^{\text {th }}$ August 2002). Kuala Lumpur is similar to China and Bangladesh where floods were due to human hand, in contrast with the Netherlands and Germany where floods were natural disasters.

Understanding the flood problem begins by finding out its root cause. The root cause is uncovered through the systematic approach of evaluating the causes of flood in urban areas such as Kuala Lumpur. A systematic approach would encompass a selection of criteria that can determine which, from a range of factors, are the root causes of flood. By establishing the root causes of flood measures can be taken to solve the flood problem from a specific scope of recommendations.

Working out the factors that cause floods is important although arguably there could be conflicting results. This is due to the complexity and reality of the problem and is based on the evaluation of authorities with different expertise and specialisations. The complexity of the problem could prevent any definite measure to be recommended for flood mitigation. However, short-term and long-term initiatives are recommended.

This study evaluates the significance of factors that cause urban flash floods at the Sg. ${ }^{5}$ Gombak catchment area within Kuala Lumpur by using the MultiCriteria Analysis (also called the Multiple Criteria Decision Analysis (MCDA)) method. The application of MCA in this study has shown its effectiveness in assisting urban planners, authorities, decision makers, stakeholders and the public or end users as stated in Spatial Planning And Decision Support System For Modelling Water Resources (Alias Abdullah et al., 2004), and Evaluating Rail Network Options Using MCDA (Ali Sharifi et al., 2004). It is aimed to assist parties who have an interest in urban flooding to take measures that will mitigate the hazards in the study area through long-term and short-term initiatives

\footnotetext{
${ }^{4}$ Ministerie van Buitelandse Zaker, 2005

${ }^{5}$ Sg. represents sungai or river. E.g., Sg. Gombak means Gombak River.
} 


\section{The Problem}

The Klang Valley (comprising of Kuala Lumpur and five other districts in Selangor State) has grown to encompass a wide expanse of highly urbanised area since 1860 as people from the rural areas had begun to migrate to the towns in hopes of a better life. Lack of proper planning back then forced many to set up squatter colonies. The advent of urbanisation saw Kuala Lumpur face many problems both social and physical in nature. The ad-hoc town gave way to a rapidly developing but unplanned city that grew dangerously close to the rivers. In the past, the occurrence of these floods is notably more often and more vicious. According to Salmah (2004), the problem of increased occurrences of flash floods in the Klang Valley is a consequence of unplanned development in the flood plains, resulting in changes to the environment.

There are two main rivers in Kuala Lumpur that are most prone to flooding due to their close proximity to urban areas, specifically Sg. Gombak and Sg. Klang. There is much evidence of public and drainage works being done to control the flooding of Sg. Klang such as the Stormwater Management and Road Tunnel $\left(\right.$ SMART) ${ }^{6}$, a two-pronged project under the Federal Government to alleviate the flood problem and ease traffic congestion in Kuala Lumpur city centre. On the other hand, there has been no news as yet of flood control measures intended for Sg. Gombak. Thus, Sg. Gombak catchment area within Kuala Lumpur is the case for this study and a reference for the MCA evaluation (see Figure 1).

There can be many causes of flood in Sg. Gombak due to the natural phenomena. However, the main factors that cause floods in urban areas like Kuala Lumpur mostly stem from human activities.

The first factor is land use change (here we called it as land factor). For the past fifty years the morphology of Kuala Lumpur had significantly changed from a known mining town to a modern capital city. The rapid urbanisation process had made Kuala Lumpur a modern concrete jungle. Empirical studies by scholars from various universities and research institutes had showed that floods in Kuala Lumpur and Klang Valley were due to impervious land or ground surfaces that cannot absorb water into the soil effectively thus causing flood at areas closest to the rivers.

${ }^{6}$ SMART is an acronym for Stormwater Management and Road Tunnel, a project under the Federal Government of Malaysia initiated to alleviate the flooding problem in the city centre of Kuala Lumpur. See http://www.smarttunnel.com.my/home.htm on the project. 


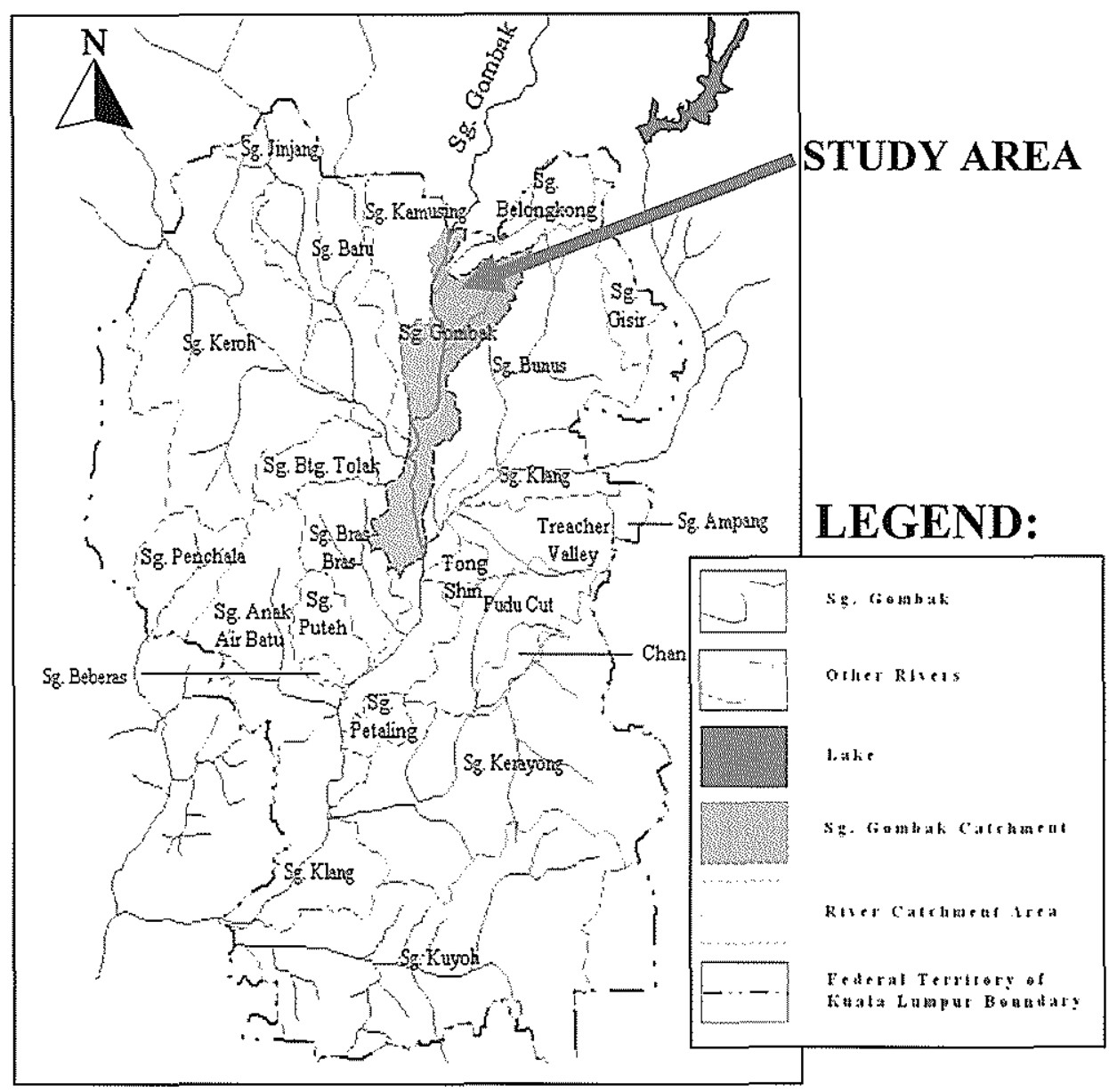

Figure 1: The Study Area of Sg. Gombak, Kuala Lumpur

The second factor is Sg. Gombak does not have the capacity to drain off water quickly during heavy rain. In the ' 90 s, it was cited that the cause for flooding in the Kuala Lumpur city centre was due to clogging of drains and its capacity to hold very low volume of water.

The third factor is heavy rain as the cause of flooding. Floods occur more often during the monsoon season as the monsoon storms rain heavily on the west coast of Peninsular Malaysia. Other weather factors that contribute to flooding are such as the global La Nina effect. As the monsoon storms follow a set pattern each year, there should be increased ability to manage the weather 
effects. Even so, more often than not urban flooding also occurs after only a light evening shower.

\section{OBJECTIVE}

The main objective is to find out systematically the most significant urban flood factor of highest priority in Sg. Gombak catchment area within Kuala Lumpur. The systematic evaluation uses MCA, which includes weight assignation of a selection of criteria by authorities and pairwise comparison of the objectives of each authority. Four government departments namely DID (Department of Irrigation and Drainage), DOE (Department of Environment), DBKL (Kuala Lumpur Citty Hall) and MMD (Malaysian MeteorologicaL Department), are chosen for the interview due to their relevance to the study area and scope of work.

\section{RIVER HYDROLOGY AND THE CHARACTERISTICS OF URBAN FLOODS}

Urban flood characteristics are different from rural floods. Firstly there must be a definition of what is known as 'urban area' and secondly what is the definition of 'flood'. From then on, the collective term of 'urban flood' can be better understood in terms of physical area where it occurs, its causes or factors, and its basic dynamics. Through the understanding of urban floods, criteria (including its respective indicator) for urban flood improvement are then derived and selected for the weight assignation and evaluation exercise.

\section{URBAN FLOOD OCCURRENCE FACTORS}

The factors are generally reasons that cause and intensify flood events in urban areas. Smith (1998) summarises the factors of flood occurrence - rain, basin (stable and variable), and channel factors (refer Figure 2). 


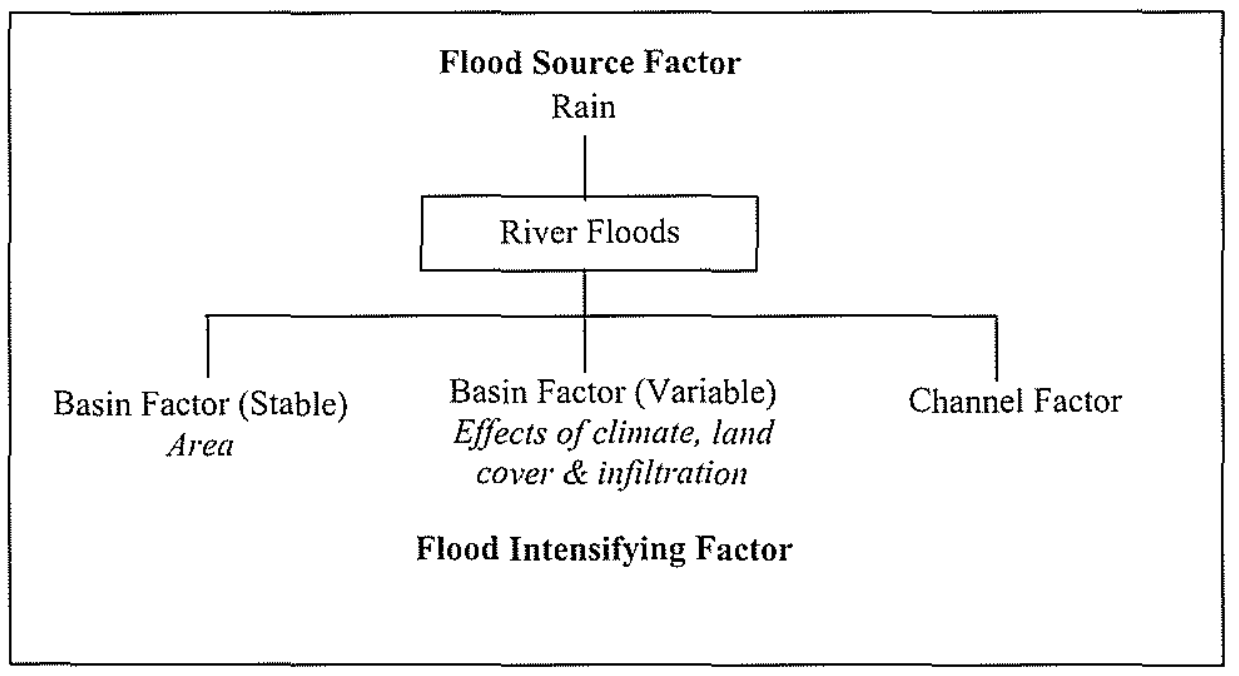

Figure 2: Flood cause factor and flood intensifying factors (After Smith, 1998)

\section{FLOOD MITIGATION AUTHORITIES RELATED TO SG. GOMBAK CATCHMENT AREA}

Understanding the organisation of authorities in charge of flood mitigation is imperative so that the choice of authorities to be interviewed will focus on the problem at hand. Only four authorities are selected for the interview so that their overall opinions will give an overview to the flood problem in Sg. Gombak. The first would be the authority responsible for planning and development of land within Sg. Gombak catchment area (i.e. DBKL), and the second is the authority responsible for the Sg. Gombak watercourse (i.e. DID). The third would be the authority responsible for the environment as a whole (i.e. DOE) and the fourth is the authority that can forecast the flood-causing weather (i.e. MMD).

\section{MCA EVALUATION AND FINDINGS}

The multiple criteria evaluation (MCE) of the flood factors is carried out based on the performances of each factor on various defined criteria and the relative importance of each criterion. The objective data is derived through assessment of the land use and environmental impacts of each flood factor interviews and processed using MCDA. In observing the performance of each flood factor on a different criterion shows that there is one option that dominates the others. This 
is expected although the flood factors are comparable to each other due to the nature of the problem. The result of this process is given in the "effects table".

The subjective information relates to the relative importance of objectives and criteria valued in interviews using the pairwise comparison method. In this process, the authorities made judgements on the relative importance of three main objectives in obtaining the flood factor i.e. physical planning, engineering and environmental objectives. Physical planning is important because the study area is located in a highly built-up area and therefore planning is essential, whereas engineering objective is included for the stream aspect, and lastly, environmental objective is to present the ecological aspect of the problem. The authorities interviewed include DID, DBKL, DOE, and MMD.

\section{A structured pairwise comparison as the assessment procedure}

Structured pairwise comparison is a priority assessment procedure, a judgement on the relative importance of the three main objectives outlined, namely physical planning, engineering and environmental aspects. Using the pairwise comparison method, the representatives of authorities made an assessment on the priorities of objectives. For this process the following procedure was used.

The main objectives were presented in a table such as Table 1 . Then, each representative was asked to rank the importance or relevance of the main objectives of the flood factors as seen by each authority. Table 1 depicts the outcome of the survey of various authorities.

The representatives then rank the order of importance between each of the objectives. Using the information in Table 1 for a structured pairwise comparison technique, the relative importance of the objectives and criteria for each authority was derived. Table 2 presents the relative importance of the main objectives as derived from Table 1.

Based on Table 1 that presents the relative importance of the main objectives as perceived by each authority, three out of four authorities stated identical relative importance of the main objectives. In the survey, all the authorities feel that the physical planning objective is relatively strongly more important than the other objectives when it comes to evaluating flood occurrence factors. However, in the opinion of $\mathrm{MMD}$, the environmental objective is less important as the natural environment can be controlled or predicted only to a certain extent such as rainfall, wind flow, weather pattern, etc. 
Table 1: Summary of relative importance of the main objectives as perceived by each authority

\begin{tabular}{|c|c|c|c|c|c|}
\hline & $\begin{array}{c}\text { Weakly } \\
\text { more } \\
\text { important }\end{array}$ & $\begin{array}{c}\text { Strongly } \\
\text { more } \\
\text { important }\end{array}$ & & $\begin{array}{c}\text { Weakly } \\
\text { more } \\
\text { important }\end{array}$ & $\begin{array}{l}\text { Strongly } \\
\text { more } \\
\text { important }\end{array}$ \\
\hline DID & & & DOE & & \\
\hline $\begin{array}{l}\text { Physical } \\
\text { Planning }\end{array}$ & & $\mathrm{X}$ & $\begin{array}{l}\text { Physical } \\
\text { Planning }\end{array}$ & & $\mathrm{X}$ \\
\hline Engineering & $\mathrm{X}$ & & Engineering & & $\mathrm{X}$ \\
\hline Environment & $\mathrm{X}$ & & Environment & $\mathrm{X}$ & \\
\hline DBKL & & & MMD & & \\
\hline $\begin{array}{l}\text { Physical } \\
\text { Planning }\end{array}$ & & $\mathrm{X}$ & $\begin{array}{l}\text { Physical } \\
\text { Planning }\end{array}$ & & $\mathrm{X}$ \\
\hline Engineering & $\mathrm{X}$ & & Engineering & $x$ & \\
\hline Environment & $\mathrm{X}$ & & Environment & $X$ & \\
\hline
\end{tabular}

According to DID, the physical planning is most important especially in the integration of drainage to the urban layout for channeling runoff and floodwaters especially from critical points. DBKL also agrees in this respect, not only with the view that proper physical planning can help mitigate flooding near the city centre but also on enforcement of garbage dumping into the river. In the opinion of $\mathrm{DOE}$, the engineering objective also has strong importance in this study because the engineering aspect of the river plays a significant role in controlling and mitigating flood; such as those that contribute to smooth flow of water including shape of streambed and its material, sedimentation rate, etc.

Table 2 shows the detailed results of the structured pairwise comparison method that was calculated. The authority that assigned the highest weight to physical planning objective is DBKL. With Kuala Lumpur geared towards excellent standards (world-class), the physical aspect is most important. This view is also somewhat shared by DID. 
Table 2: Structured pairwise comparison method

(weights translation as perceived by each authority)

\begin{tabular}{|l|c|c|}
\hline \multicolumn{1}{|c|}{ DID } & Weight & (\%) \\
\hline Physical Planning & 0.694 & 69.4 \\
\hline Engineering & 0.128 & 12.8 \\
\hline Environment & 0.178 & 17.8 \\
\hline \multicolumn{1}{|c|}{ DOE } & & \\
\hline Physical Planning & 0.439 & 43.9 \\
\hline Engineering & 0.323 & 32.3 \\
\hline Environment & 0.238 & 23.8 \\
\hline \multicolumn{1}{|c|}{ DBKL } & & \\
\hline \multicolumn{1}{|c|}{ MMD } & 0.704 & 70.4 \\
\hline Physical Planning & 0.154 & 15.4 \\
\hline Engineering & 0.142 & 14.2 \\
\hline Environment & & \\
\hline & & \\
\hline \multicolumn{1}{|c|}{} & 0.582 & 58.2 \\
\hline Physical Planning & 0.258 & 25.8 \\
\hline Engineering & & 16.0 \\
\hline Environment & & \\
\hline
\end{tabular}

The physical planning objective is important as stated by DID for practical aspects. In the survey of the authority representatives' opinion, much of their work involves laying down drainage at the most appropriate location besides monitoring and maintaining it. This calls for a lot of time spent on planning, research, and cost, therefore making the physical planning objective their concern in order not to waste valuable time, manpower and money. Like DBKL, engineering and environmental objectives are lesser concerns in terms of flooding although it was stressed that DID pays equal attention to all objectives. This is due to engineering being a means to mitigate flood before it happens i.e. river and drainage construction, whereas environment is beyond their scope of work. 
With both DOE and MMD, although the weight is definitely more on physical planning, it appears as if both authorities' representatives balance their views to encompass the bigger picture. The weights assigned to all three objectives are more evenly spread although not to the point of being equal. There being no doubt that physical planning is the objective with the highest weight in all four authorities, the second highest weight on engineering and lowest weight on environmental objectives was also assigned by all except for DID.

\section{Evaluation objectives, criteria and indicators}

With the authorities' rank of objective importance known, evaluation of the flood factors commences with the basic outline of objectives, criteria and indicators of the study. The table summarising this is reproduced and rearranged with the inclusion of the MCDA objectives as shown in Table 3. Figure 3 illustrates the structure of MCA evaluation.

Table 3: Objectives, criteria and indicators in evaluating urban flood occurrence

\begin{tabular}{|c|c|c|}
\hline $\begin{array}{c}\text { MAIN } \\
\text { OBJECTIVES }\end{array}$ & CRITERIA & INDICATOR \\
\hline \multirow{3}{*}{$\begin{array}{l}\text { PHYSICAL } \\
\text { PLANNING } \\
\text { OBJECTIVES }\end{array}$} & $\begin{array}{l}\text { a. Maximise natural } \\
\text { absorption } \\
\text { mechanism }\end{array}$ & $\begin{array}{l}\text { Natural ground cover } \\
\text { designated for each flood } \\
\text { factor to prevent flood }\end{array}$ \\
\hline & $\begin{array}{l}\text { b. Minimise built-up } \\
\text { density in the urban } \\
\text { area }\end{array}$ & $\begin{array}{l}\text { Developed area within } \\
\text { catchment that delays water } \\
\text { flow into ground or stream }\end{array}$ \\
\hline & $\begin{array}{l}\text { c. Maximise strategic } \\
\text { initiatives in } \\
\text { managing river and } \\
\text { flood issue }\end{array}$ & $\begin{array}{l}\text { Strategic plans implemented } \\
\text { within the last } 5 \text { years for } \\
\text { floods }\end{array}$ \\
\hline \multirow{3}{*}{$\begin{array}{l}\text { ENGINEERING } \\
\text { OBJECTIVES }\end{array}$} & $\begin{array}{l}\text { d. Maximise specific } \\
\text { and scientific data on } \\
\text { frequency and } \\
\text { magnitude of flooding }\end{array}$ & $\begin{array}{l}\text { Number of floods in } 2003- \\
2004 \text { caused by each factor }\end{array}$ \\
\hline & $\begin{array}{l}\text { Maximise utilisation } \\
\text { of flood waming } \\
\text { system }\end{array}$ & $\begin{array}{l}\text { Usage of flood warning } \\
\text { board / siren }\end{array}$ \\
\hline & & \\
\hline
\end{tabular}




\begin{tabular}{|c|c|c|}
\hline $\begin{array}{c}\text { MAIN } \\
\text { OBJECTIVES }\end{array}$ & CRITERIA & INDICATOR \\
\hline \multirow[b]{3}{*}{$\begin{array}{l}\text { ENVIRONMENTAL } \\
\text { OBJECTIVES }\end{array}$} & $\begin{array}{l}f . \text { Maximise river } \\
\text { conservation } \\
\text { (naturalness of the } \\
\text { river) }\end{array}$ & $\begin{array}{l}\text { Percent length of river with } \\
\text { natural bank }\end{array}$ \\
\hline & $\begin{array}{l}\text { g. Minimise river } \\
\text { modifications }\end{array}$ & $\begin{array}{l}\text { Percent length of river with } \\
\text { modified bank }\end{array}$ \\
\hline & $\begin{array}{l}\text { h. Maximise experts' } \\
\text { knowledge to study } \\
\text { on urban flood } \\
\text { problems (including } \\
\text { decision makers, } \\
\text { stakeholders, } \\
\text { engineers and } \\
\text { planners) }\end{array}$ & $\begin{array}{l}\text { No. of studies conducted on } \\
\text { flood }\end{array}$ \\
\hline
\end{tabular}

The three main objectives of this study are underpinned by certain criteria. The criteria are to achieve the objectives of the study through indicators. Next, with the criteria and indicators on hand, the "effects table" is developed specifically for this study, the element on which multi-criteria evaluation ${ }^{7}$ is based upon. It consists of rows of indicators outlined previously (also known as "effects" in this exercise), and columns of urban flood factors. The urban flood factors in this study are three; namely land (as in relation to urbanisation), stream (as in relation to drainage) and rain (as in relation to weather). In the boxes where indicators and flood factors correspond, the performances of the indicators are assigned in appropriate units.

This data input into the effects table was done by the four representatives of the authorities; namely DID, DOE, DBKL and MMD. Looking at the main objectives, physical planning aspect is reflected in DBKL as one of the authorities, engineering aspect is reflected in DID and partly the DOE, and the environment aspect is reflected in DOE and MMD. All the interviewees are from the public sector because a greater number of people are affected by the decisions that are made in comparison with other sectors such as NGOs and private sector. The method of data input is through interview and telephone

\footnotetext{
${ }^{7}$ DEFINITE2.0 software (2000) was developed by the Institute for Environmental Studies, Vrije University, Amsterdam, The Netherlands.
} 
interview. In some cases, one officer did not have all the data required; therefore the survey is continued with other officers within the department.

Table 5 shows the effects table as filled in by representatives of the Department of Irrigation and Drainage (DID). According to DID, the data in this effects table is estimation and is not conclusive.

Table 5: Effects table showing performance of each flood occurrence factor - DID, Kuala Lumpur

\begin{tabular}{|c|c|c|c|c|}
\hline Department of Irrigation and & Unit & Land & Stream & Rain \\
\hline \multicolumn{5}{|l|}{ PHYSICAL PLANNING OBJECTIVES } \\
\hline \multicolumn{5}{|c|}{ a. Maximise natural absorption mechanism } \\
\hline $\begin{array}{l}\text { Natural ground cover designated } \\
\text { to prevent flood (for each flood } \\
\text { factor) }\end{array}$ & $\%$ & 12 & 15 & 0 \\
\hline \multicolumn{5}{|c|}{ b. Minimise built-up density in the urban area } \\
\hline $\begin{array}{l}\text { Developed area within catchment } \\
\text { that delays water flow into } \\
\text { ground or stream }\end{array}$ & $\%$ & 80 & 15 & 5 \\
\hline \multicolumn{5}{|c|}{ c. Maximise strategic initiatives in managing river and flood issue } \\
\hline $\begin{array}{l}\text { Strategic plans implemented } \\
\text { within the last } 5 \text { years (for flood } \\
\text { mitigation) }\end{array}$ & $\begin{array}{l}\text { No. of } \\
\text { strategies }\end{array}$ & 2 & 1 & 0 \\
\hline \multicolumn{5}{|l|}{ ENGINEERING OBJECTIVES } \\
\hline \multicolumn{5}{|c|}{$\begin{array}{l}\text { d. Maximise specific and scientific data on frequency and magnitude of } \\
\text { flooding }\end{array}$} \\
\hline $\begin{array}{l}\text { Number of floods in } 2003-2004 \\
\text { caused by each factor }\end{array}$ & $\begin{array}{l}\text { No. of } \\
\text { events }\end{array}$ & 0 & 0 & 5 \\
\hline \multicolumn{5}{|c|}{ e. Maximise utilisation of flood warning system } \\
\hline $\begin{array}{l}\text { Usage of flood warning board / } \\
\text { siren in } 2003-2004\end{array}$ & $\begin{array}{l}\text { No. of } \\
\text { times }\end{array}$ & 3 & 3 & 0 \\
\hline \multicolumn{5}{|l|}{ ENVIRONMENTAL OBJECTIVES } \\
\hline \multicolumn{5}{|c|}{ f. Maximise river conservation (naturalness of the river) } \\
\hline $\begin{array}{l}\text { Percent length of river with } \\
\text { natural bank }\end{array}$ & $\%$ & 30 & 5 & 0 \\
\hline \multicolumn{5}{|l|}{ g. Minimise river modifications } \\
\hline $\begin{array}{l}\text { Percent length of river with } \\
\text { modified bank }\end{array}$ & $\%$ & 70 & 95 & 0 \\
\hline \multicolumn{5}{|c|}{$\begin{array}{l}\text { h. Maximise experts' knowledge to study on urban flood problems (including } \\
\text { decision makers, stakeholders, engineers and planners) }\end{array}$} \\
\hline $\begin{array}{l}\text { No. of studies conducted on flood } \\
\text { in the last } 5 \text { years }\end{array}$ & $\begin{array}{l}\text { No. of } \\
\text { studies }\end{array}$ & 0 & 0 & 0 \\
\hline
\end{tabular}




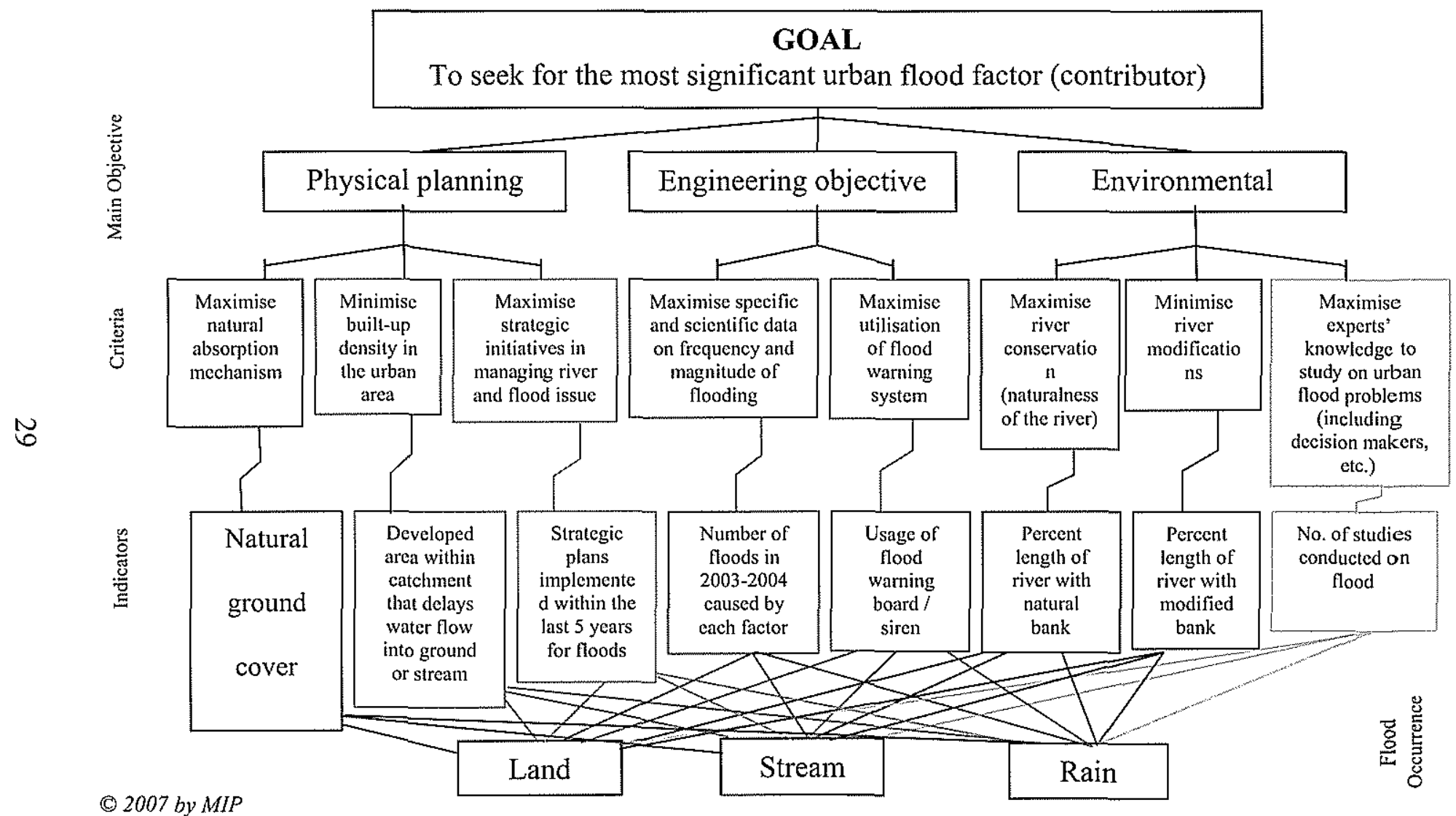

Figure 3 : The Evaluation Structure 
Table 5: Effects table showing performance of each flood occurrence factor - DID, Kuala Lumpur

\begin{tabular}{|c|c|c|c|c|}
\hline Department of Irrigation and & Unit & Land & Stream & Rain \\
\hline \multicolumn{5}{|l|}{ PHYSICAL PLANNING OBJECTIVES } \\
\hline \multicolumn{5}{|c|}{ i. Maximise natural absorption mechanism } \\
\hline $\begin{array}{l}\text { Natural ground cover designated } \\
\text { to prevent flood (for each flood } \\
\text { factor) }\end{array}$ & $\%$ & 12 & 15 & 0 \\
\hline \multicolumn{5}{|c|}{ j. Minimise built-up density in the urban area } \\
\hline $\begin{array}{l}\text { Developed area within catchment } \\
\text { that delays water flow into } \\
\text { ground or stream }\end{array}$ & $\%$ & 80 & 15 & 5 \\
\hline \multicolumn{5}{|c|}{ k. Maximise strategic initiatives in managing river and flood issue } \\
\hline $\begin{array}{l}\text { Strategic plans implemented } \\
\text { within the last } 5 \text { years (for flood } \\
\text { mitigation) }\end{array}$ & $\begin{array}{c}\text { No. of } \\
\text { strategies }\end{array}$ & 2 & 1 & 0 \\
\hline \multicolumn{5}{|l|}{ ENGINEERING OBJECTIVES } \\
\hline \multicolumn{5}{|c|}{$\begin{array}{l}\text { 1. Maximise specific and scientific data on frequency and magnitude of } \\
\text { flooding }\end{array}$} \\
\hline $\begin{array}{l}\text { Number of floods in } 2003-2004 \\
\text { caused by each factor }\end{array}$ & $\begin{array}{l}\text { No. of } \\
\text { events }\end{array}$ & 0 & 0 & 5 \\
\hline \multicolumn{5}{|c|}{ m. Maximise utilisation of flood warning system } \\
\hline $\begin{array}{l}\text { Usage of flood warning board / } \\
\text { siren in } 2003-2004\end{array}$ & $\begin{array}{l}\text { No. of } \\
\text { times }\end{array}$ & 3 & 3 & 0 \\
\hline \multicolumn{5}{|l|}{ ENVIRONMENTAL OBJECTIVES } \\
\hline \multicolumn{5}{|c|}{ n. Maximise river conservation (naturalness of the river) } \\
\hline $\begin{array}{l}\text { Percent length of river with } \\
\text { natural bank }\end{array}$ & $\%$ & 30 & 5 & 0 \\
\hline \multicolumn{5}{|l|}{ o. Minimise river modifications } \\
\hline $\begin{array}{l}\text { Percent length of river with } \\
\text { modified bank }\end{array}$ & $\%$ & 70 & 95 & 0 \\
\hline \multicolumn{5}{|c|}{$\begin{array}{l}\text { p. Maximise experts' knowledge to study on urban flood problems (including } \\
\text { decision makers, stakeholders, engineers and planners) }\end{array}$} \\
\hline $\begin{array}{l}\text { No. of studies conducted on flood } \\
\text { in the last } 5 \text { years }\end{array}$ & $\begin{array}{l}\text { No. of } \\
\text { studies }\end{array}$ & 0 & 0 & 0 \\
\hline
\end{tabular}


Table 6: Effects table showing performance of each flood occurrence factor - DOE, Kuala Lumpur

\begin{tabular}{|c|c|c|c|c|}
\hline Department of Environment & Unit & Land & Stream & Rain \\
\hline \multicolumn{5}{|l|}{ PHYSICAL PLANNING OBJECTIVES } \\
\hline \multicolumn{5}{|l|}{ a. Maximise absorption of excess water } \\
\hline $\begin{array}{l}\text { Natural ground cover designated } \\
\text { to prevent flood (for each flood } \\
\text { factor) }\end{array}$ & $\%$ & 7 & 30 & 5 \\
\hline \multicolumn{5}{|c|}{ b. Minimise built-up area density in the urban area } \\
\hline $\begin{array}{l}\text { Developed area within catchment } \\
\text { that delays water flow into } \\
\text { ground or stream }\end{array}$ & $\%$ & 75 & 15 & 3 \\
\hline \multicolumn{5}{|c|}{ c. Maximise strategic initiatives in managing river and flood issue } \\
\hline $\begin{array}{l}\text { Strategic plans implemented } \\
\text { within the last } 5 \text { years (for flood } \\
\text { mitigation) }\end{array}$ & $\begin{array}{l}\text { No. of } \\
\text { strategie } \\
\text { s }\end{array}$ & 3 & 2 & 0 \\
\hline \multicolumn{5}{|l|}{ ENGINEERING OBJECTIVES } \\
\hline \multicolumn{5}{|c|}{$\begin{array}{l}\text { d. Maximise specific and scientific data on frequency and magnitude of } \\
\text { flooding }\end{array}$} \\
\hline $\begin{array}{l}\text { Number of floods in } 2003-2004 \\
\text { caused by each factor }\end{array}$ & $\begin{array}{l}\text { No. of } \\
\text { events }\end{array}$ & 3 & 2 & 3 \\
\hline \multicolumn{5}{|c|}{ e. Maximise utilisation of flood warning system } \\
\hline $\begin{array}{l}\text { Usage of flood warning board / } \\
\text { siren in } 2003-2004\end{array}$ & $\begin{array}{l}\text { No. of } \\
\text { times }\end{array}$ & 0 & 3 & 5 \\
\hline \multicolumn{5}{|l|}{ ENVIRONMENTAL OBJECTIVES } \\
\hline \multicolumn{5}{|c|}{ f. Maximise river conservation (naturalness of the river) } \\
\hline $\begin{array}{l}\text { Percent length of river with } \\
\text { natural bank }\end{array}$ & $\%$ & 15 & 15 & 70 \\
\hline \multicolumn{5}{|l|}{ g. Minimise river modifications } \\
\hline $\begin{array}{l}\text { Percent length of river with } \\
\text { modified bank }\end{array}$ & $\%$ & 15 & 80 & 5 \\
\hline \multicolumn{5}{|c|}{$\begin{array}{l}\text { h. Maximise experts' knowledge to study on urban flood problems (including } \\
\text { decision makers, stakeholders, engineers and planners) }\end{array}$} \\
\hline No. of studies conducted on flood & $\begin{array}{l}\text { No. of } \\
\text { studies }\end{array}$ & 0 & 0 & 0 \\
\hline
\end{tabular}


Table 7: Effects table showing performance of each flood occurrence factor - DBKL

\begin{tabular}{|c|c|c|c|c|}
\hline Kuala Lumpur City Hall & Unit & land & Stream & Rainfall \\
\hline \multicolumn{5}{|l|}{ PHYSICAL PLANNING OBJECTIVES } \\
\hline \multicolumn{5}{|l|}{ a. Maximise absorption of excess water } \\
\hline $\begin{array}{l}\text { Natural ground cover } \\
\text { designated to prevent flood (for } \\
\text { each flood factor) }\end{array}$ & $\%$ & 30 & 10 & 20 \\
\hline \multicolumn{5}{|c|}{ b. Minimise built-up area density in the urban area } \\
\hline $\begin{array}{l}\text { Developed area within } \\
\text { catchment that delays water } \\
\text { flow into ground or stream }\end{array}$ & $\%$ & 10 & 35 & 55 \\
\hline \multicolumn{5}{|c|}{ c. Maximise strategic initiatives in managing river and flood issue } \\
\hline $\begin{array}{l}\text { Strategic plans implemented } \\
\text { within the last } 5 \text { years (for flood } \\
\text { mitigation) }\end{array}$ & $\begin{array}{l}\text { No. of } \\
\text { strategies }\end{array}$ & 1 & 1 & 0 \\
\hline \multicolumn{5}{|l|}{ ENGINEERING OBJECTIVES } \\
\hline \multicolumn{5}{|c|}{$\begin{array}{l}\text { d. Maximise specific and scientific data on frequency and magnitude of } \\
\text { flooding }\end{array}$} \\
\hline $\begin{array}{l}\text { Number of floods in } 2003-2004 \\
\text { caused by each alternative }\end{array}$ & $\begin{array}{l}\text { No. of } \\
\text { flood }\end{array}$ & 0 & 2 & 3 \\
\hline \multicolumn{5}{|c|}{ e. Maximise utilisation of flood warning system } \\
\hline $\begin{array}{l}\text { Usage of flood warning board/ } \\
\text { siren in } 2003-2004\end{array}$ & $\begin{array}{l}\text { No. of } \\
\text { times }\end{array}$ & 0 & 5 & 5 \\
\hline \multicolumn{5}{|l|}{ ENVIRONMENTAL OBJECTIVES } \\
\hline \multicolumn{5}{|c|}{ f. Maximise river conservation (naturalness of the river) } \\
\hline $\begin{array}{l}\text { Percent length of river with } \\
\text { natural bank }\end{array}$ & $\%$ & 10 & 5 & 0 \\
\hline \multicolumn{5}{|l|}{ g. Minimise river modifications } \\
\hline $\begin{array}{l}\text { Percent length of river with } \\
\text { modified bank }\end{array}$ & $\%$ & 15 & 90 & 0 \\
\hline \multicolumn{5}{|c|}{$\begin{array}{l}\text { h. Maximise experts' knowledge to study on urban flood problems (including } \\
\text { decision makers, stakeholders, engineers and planners) }\end{array}$} \\
\hline $\begin{array}{l}\text { No. of studies conducted on } \\
\text { flood }\end{array}$ & $\begin{array}{l}\text { No. of } \\
\text { studies }\end{array}$ & 1 & 1 & 0 \\
\hline
\end{tabular}


Table 8: Effects table showing performance of each flood occurrence factorMMD, Kuala Lumpur

\begin{tabular}{|c|c|c|c|c|}
\hline Malaysia Meteorology Department & Unit & Land & Stream & Rain \\
\hline \multicolumn{5}{|l|}{ PHYSICAL PLANNING OBJECTIVES } \\
\hline \multicolumn{5}{|l|}{ a. Maximise absorption of excess water } \\
\hline $\begin{array}{l}\text { Natural ground cover designated } \\
\text { to prevent flood (for each flood } \\
\text { factor) }\end{array}$ & $\%$ & 0 & 10 & 20 \\
\hline \multicolumn{5}{|c|}{ b. Minimise built-up area density in the urban area } \\
\hline $\begin{array}{l}\text { Developed area within catchment } \\
\text { that delays water flow into } \\
\text { ground or stream }\end{array}$ & $\%$ & 40 & 10 & 10 \\
\hline \multicolumn{5}{|c|}{ c. Maximise strategic initiatives in managing river and flood issue } \\
\hline $\begin{array}{l}\text { Strategic plans implemented } \\
\text { within the last } 5 \text { years (for flood } \\
\text { mitigation) }\end{array}$ & $\begin{array}{l}\text { No. of } \\
\text { strategie } \\
\text { s }\end{array}$ & 0 & 0 & 1 \\
\hline \multicolumn{5}{|l|}{ ENGINEERING OBJECTIVES } \\
\hline \multicolumn{5}{|c|}{$\begin{array}{l}\text { d. Maximise specific and scientific data on frequency and magnitude of } \\
\text { flooding }\end{array}$} \\
\hline $\begin{array}{l}\text { Number of floods in } 2003-2004 \\
\text { caused by each factor }\end{array}$ & $\begin{array}{l}\text { No. of } \\
\text { flood }\end{array}$ & 0 & 2 & 2 \\
\hline \multicolumn{5}{|c|}{ e. Maximise utilisation of flood warning system } \\
\hline $\begin{array}{l}\text { Usage of flood warning board / } \\
\text { siren }\end{array}$ & $\begin{array}{l}\text { No. of } \\
\text { times }\end{array}$ & 0 & 0 & 2 \\
\hline \multicolumn{5}{|l|}{ ENVIRONMENTAL OBJECTIVES } \\
\hline \multicolumn{5}{|c|}{ f. Maximise river conservation (naturalness of the river) } \\
\hline $\begin{array}{l}\text { Percent length of river with } \\
\text { natural bank }\end{array}$ & $\%$ & 50 & 50 & 0 \\
\hline \multicolumn{5}{|l|}{ g. Minimise river modifications } \\
\hline $\begin{array}{l}\text { Percent length of river with } \\
\text { modified bank }\end{array}$ & $\%$ & 50 & 50 & 0 \\
\hline \multicolumn{5}{|c|}{$\begin{array}{l}\text { h. Maximise experts' knowledge to study on urban flood problems (including } \\
\text { decision makers, stakeholders, engineers and planners) }\end{array}$} \\
\hline No. of studies conducted on flood & $\begin{array}{l}\text { No. of } \\
\text { studies }\end{array}$ & 0 & 0 & 2 \\
\hline
\end{tabular}

\section{Multicriteria Analysis}

After completing the objective information in the effects tables, the three flood factors were computed and analysed to show the overall performance of the flood factors. Because the indicators used to measure the performance of each factor have different units of measurement with varying magnitudes, before any 
further processing can be done, they are put through a standardisation procedure reflecting the accuracy of each of the three flood factors. At the next step the standardised indicator scores of the factors were aggregated into a composite index representing the overall accuracy of each flood factor. These overall performance scores are used to rank the three factors. The overall performance of the flood factors is shown in Figure 4, 5, 6, 7, and 8 in the following pages. The boxes similar to a bar graph are a graphic presentation of the indicators in the effects table. The higher the box is, the better the performance.

Figure 4 shows the scores of DID as mostly for land and stream factors. The DOE in Figure 5 is somewhat more balanced on average for the three factors, although for the separate indicators there are significant differences. DBKL as depicted in Figure 6, and MMD as shown in Figure 7, have markedly higher scores for the land and rain factors respectively. Figure 8 shows the overall performance of all authorities on each flood factor. 


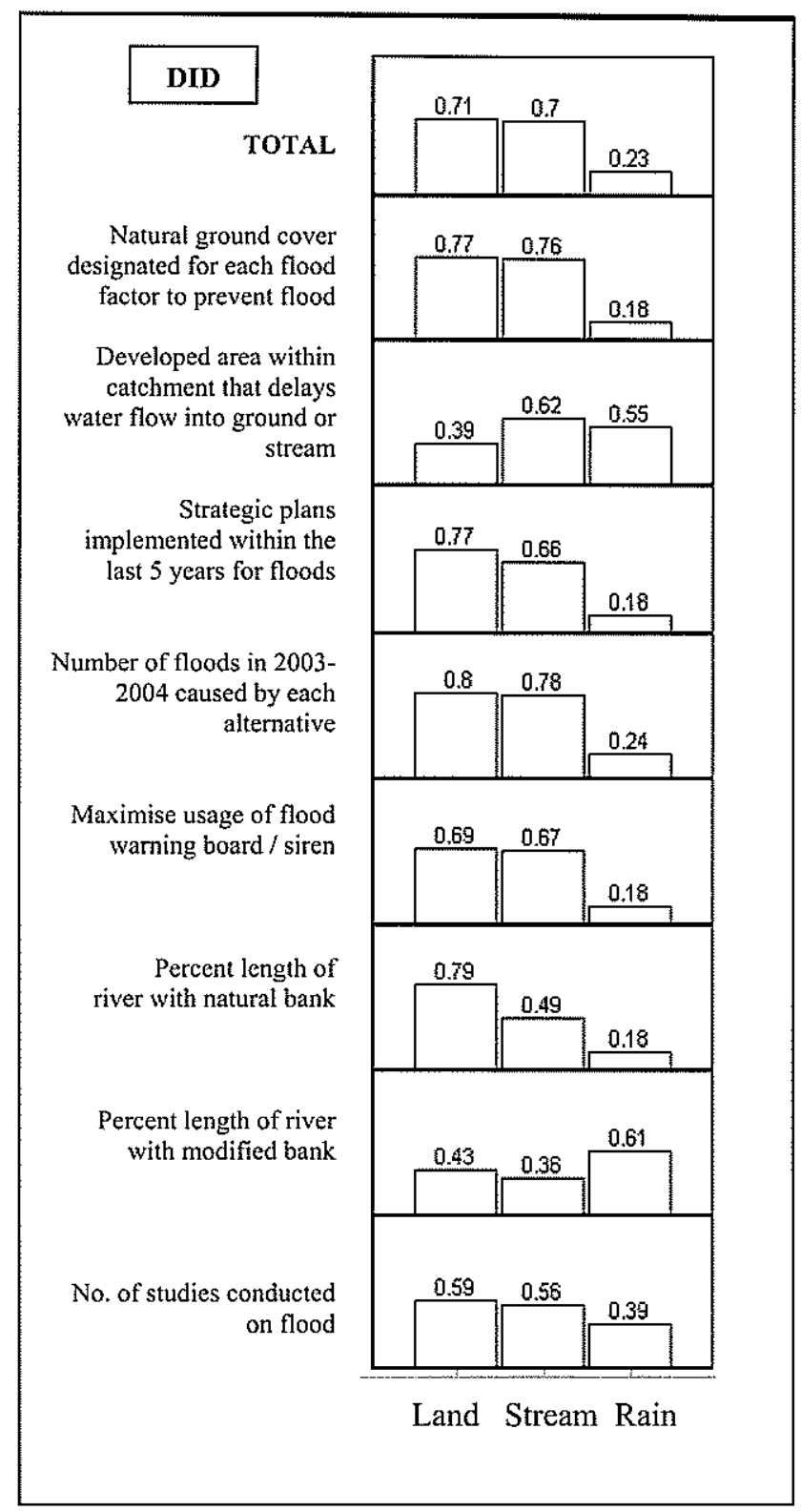

Figure 4: The overall performance of each factor on different indicators (equal weight for each objective) - Department of Irrigation and Drainage 


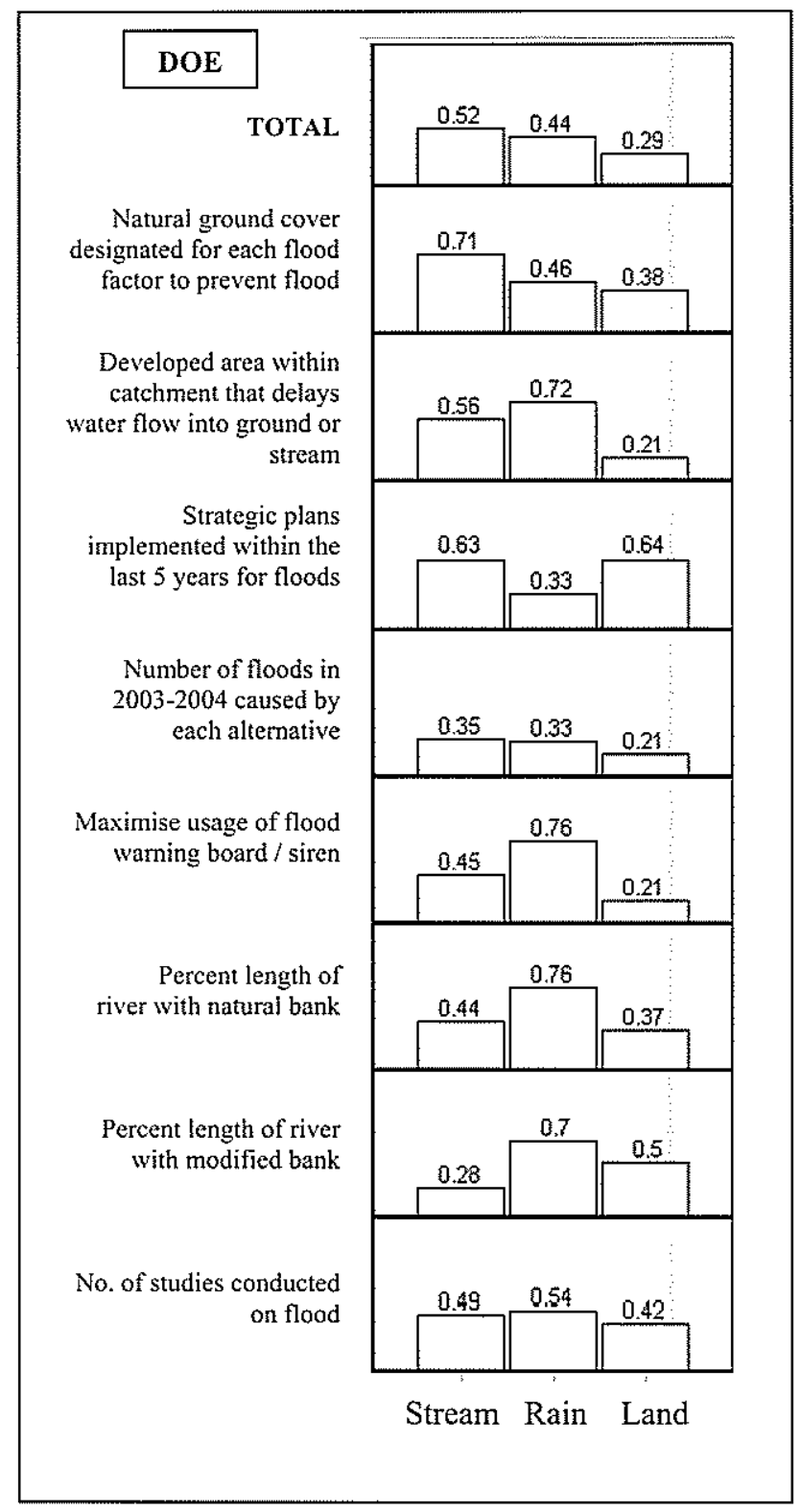

Figure 5: The overall performance of each factor on different indicators (equal weight for each objective) - Department of Environment 


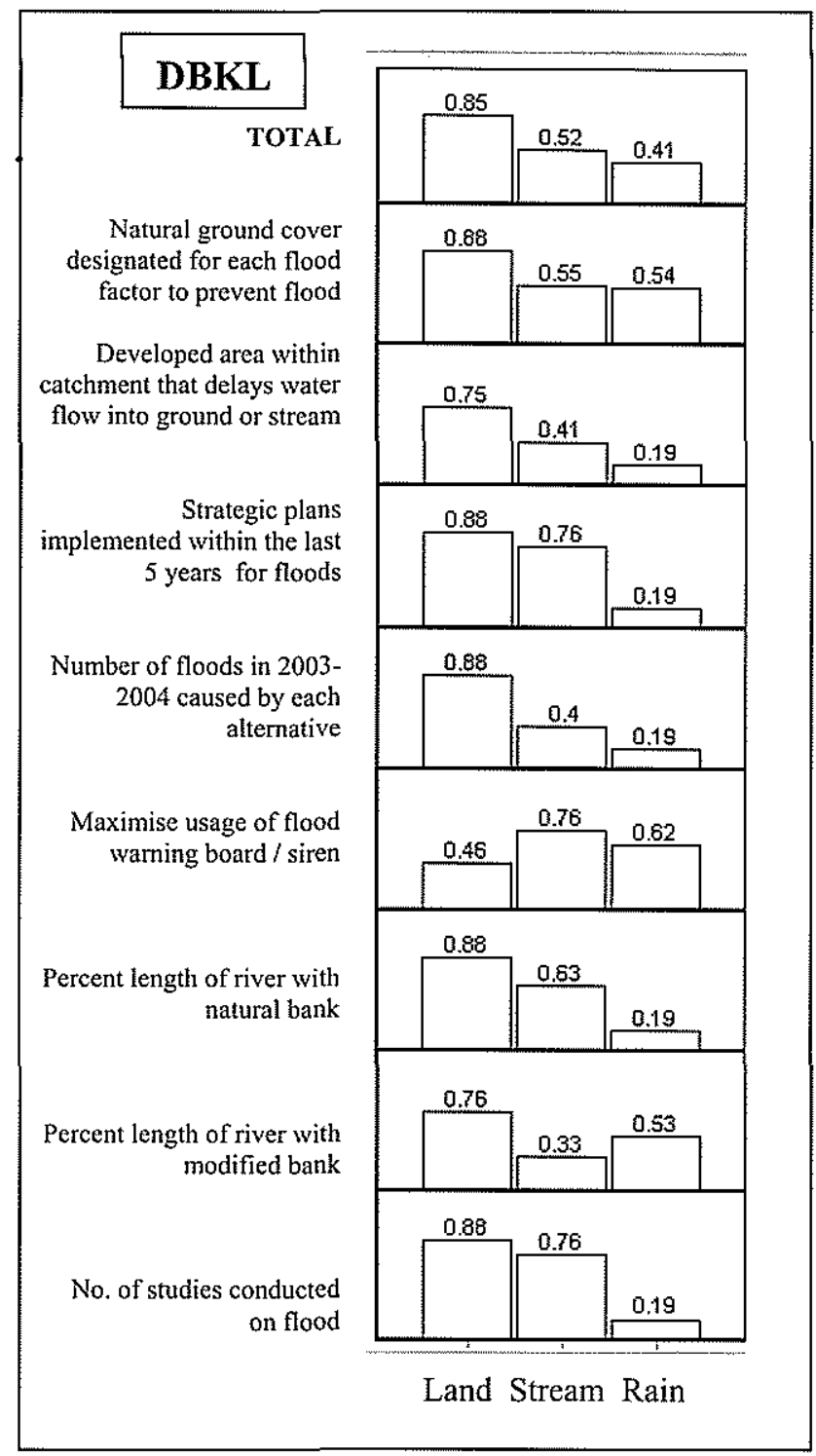

Figure 6: The overall performance of each factor on different indicators (equal weight for each objective) - City Hall Kuala Lumpur 


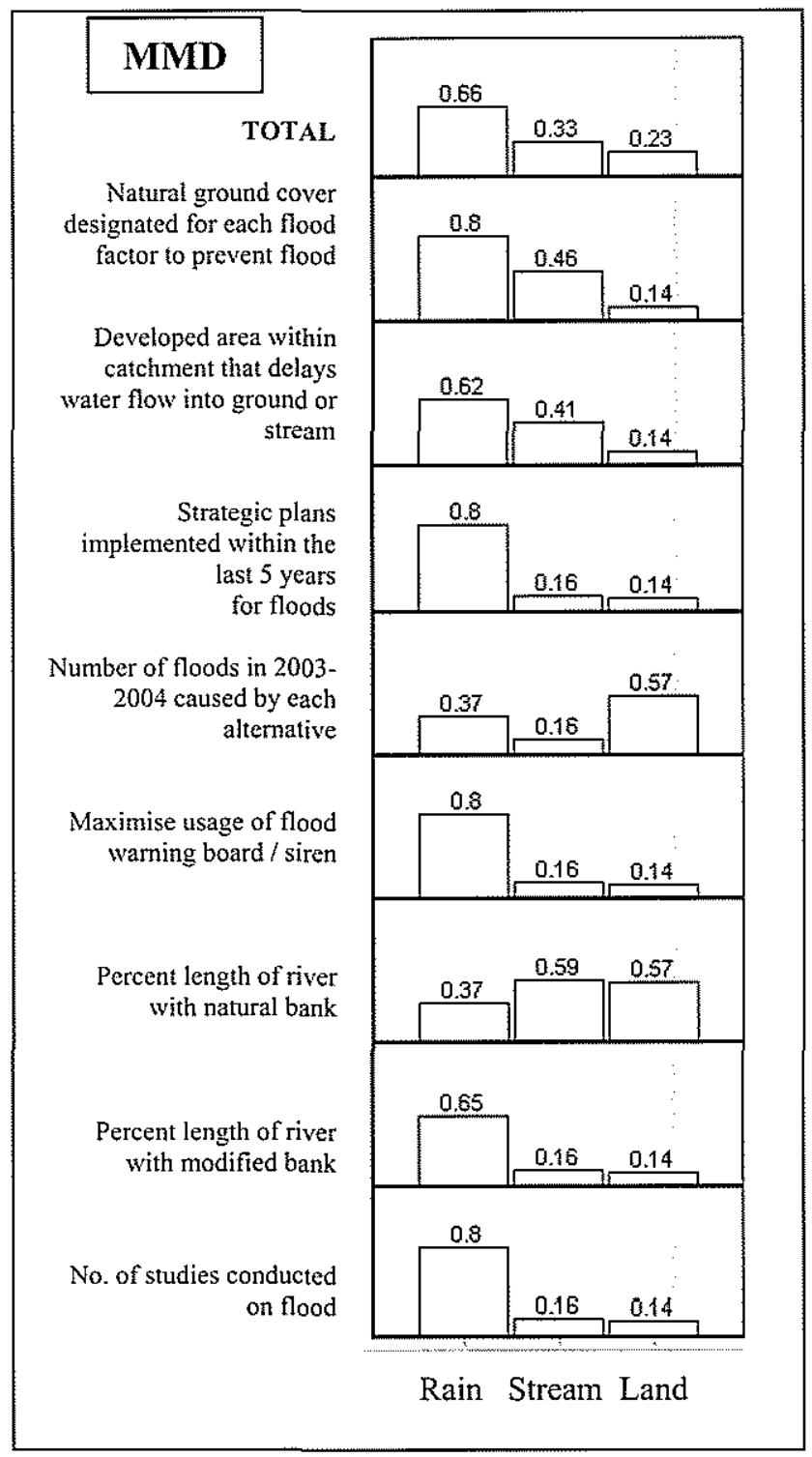

Figure 7: The overall performance of each factor on different indicators (equal weight for each objective) - Malaysian Meteorological Service 


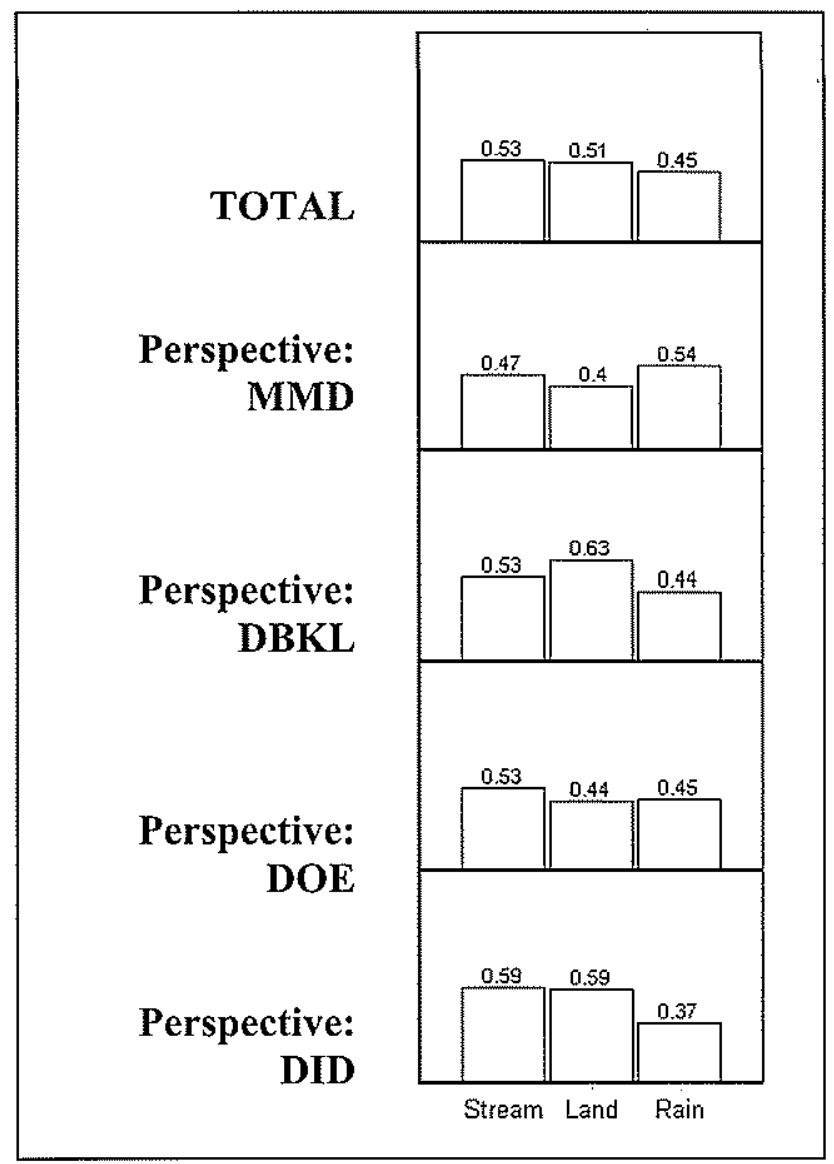

Figure 8: Overall performance of all authorities on each flood factor

From the standardisation procedure resulting in overall performance of the effects table, the performance of each indicator is now tested on the flood factors through a more detailed pairwise comparison of the importance of the effects. This second pairwise comparison has each representative assigning weights resulting in a 'weighted summation'. 'Weights' is the value assigned to each effect in comparison to other effects. The standardized values of the effects are multiplied with the effective weights of the effects. The flood factor with the highest score is considered the best. The pie corresponds to the results bar, which eventually shows the flood factor of choice of the authorities.

Unlike the first structured pairwise comparison that resulted in physical planning as being the strongly important objective, the weighted summation shows a different aspect. The DOE representative's estimation from the effects 
table shows the weighted summation results as 'stream' being the main flood factor. On the other hand, MMD representative's estimation shows the weighted summation results as 'rain'. In this aspect, DOE and MMD seem to present opposing estimation as compared to their priority assessment results.

Figure 9 shows the overall rank of each flood factor tallied to the authorities based on the previous weight summation exercise. This is to show that stream factor emerged as the first ranked flood factor, closely followed by land factor.

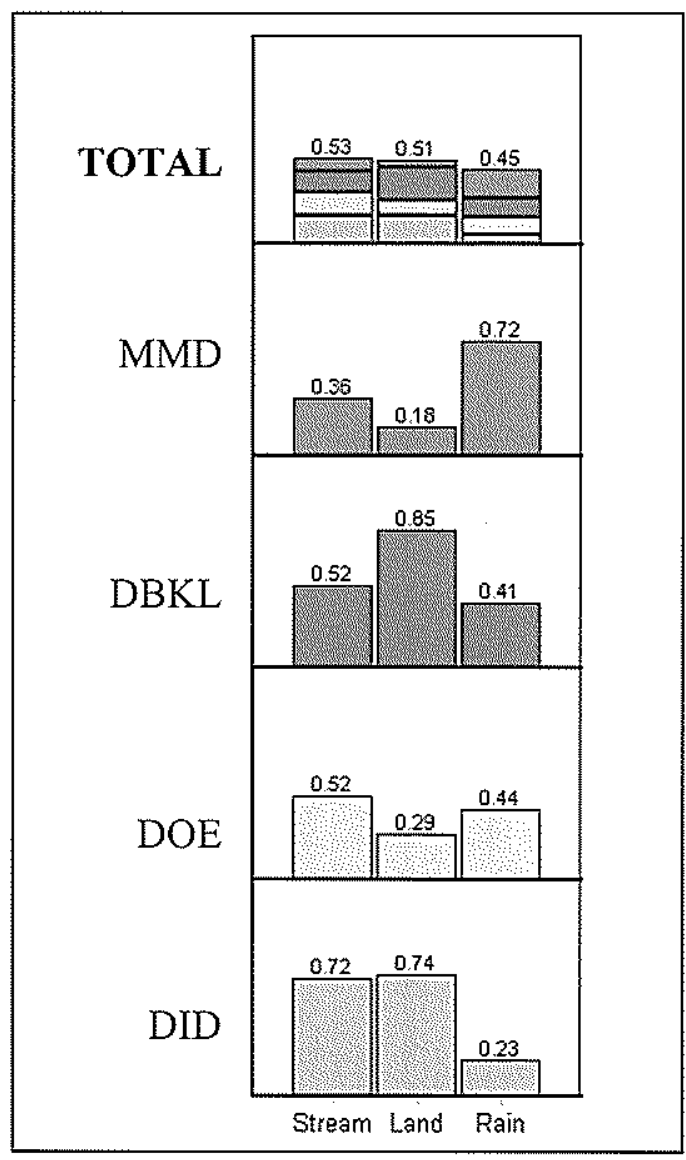

Figure 9: Overall rank of all authorities on each flood factor 


\section{CONCLUSION}

Ackoff's (1977) warning that 'an optimal solution is not an optimal solution to a problem unless a model is a perfect representation of a problem' rings true. From many dimensions such as literatures, public opinion surveys, questionnaires, etc., it is obvious that a flood is caused by any of these three major factors i.e. land, stream, and rain. This study proves that it can demonstrate a systematic approach to evaluate the major causes of urban floods.

Several conclusive outcomes can be emphasised. Firstly, through the pairwise comparison, all the four authorities agree that physical planning is the principal objective in solving flood problems in Kuala Lumpur. Secondly, the results of MCA show two out of four authorities choosing 'land' factor as the primary cause of flooding in urban area. However, the total score for 'stream' factor is slightly higher than 'land' factor even if it is the primary choice of only one authority. Thirdly, in terms of weight assignment of indicators, three out of four authorities assigned the highest weights on those indicators originating from physical planning objective in the criteria structure.

The connection between the results of pairwise comparison and MCA generally correspond to each other. Physical planning as the principal objective is consistent with 'land' factor, as in this study 'land' is a broad term for urbanisation, which is an aspect of physical planning. Thought there is no right or wrong answers, from the background study of the previous chapters it appears that the 'land' factor is indeed the topmost priority in controlling the flood problem because it is within our control.

As opposed to 'stream' and 'rain' which are natural elements that are difficult for man to change, 'land' is the only factor here that is governed by man-made laws, subject to man's activities and is directly within our control. 'Stream' and 'rain' are not $100 \%$ within our control even in terms of forecast; therefore, although each authority sets it as a priority, it does not justify their choice of physical planning as the main objective. The soil on riverbanks is naturally absorbent and can retain water. A river that is still flowing in its original form is able to retain water without bursting its banks during light rain. It is this characteristic of the river that we have to preserve by keeping the soil free from unnatural and impervious surfaces. 


\section{REFERENCES:}

Alias Abdullah et al. 2004. 'Spatial Planning and Decision Support System for Modelling Water Resources' in Water Environmental Planning: Towards Integrated Planning and Management of Water Resources for Environmental Risks, IIUM, Kuala Lumpur, pp 261-282.

Ali Sharifi et al. 2004. 'Evaluating Rail Network Options Using Multiple Criteria Decision Analysis: Case Study Klang Valley, Malaysia' in Applications of Planning and Decision Support Systems, IIUM, Kuala Lumpur, pp 21-60.

Salmah Zakaria 2004. 'Integrated River Basin Management' in Water Environmental Planning: Towards Integrated Planning and Management of Water Resources for Environmental Risks, IIUM, Kuala Lumpur, pp 1944.

Malczewski, Jacek 1999. GIS and Multicriteria Decision Analysis, John Wiley $\&$ Sons Inc, New York.

Asakawa S. et al. 2004. 'Landscape change and the urbanisation process in Europe' in International Journal of Landscape and Urban Planning, Vol. 67, Elsevier, pp. 9-26.

Asian Development Bank 2002. Handbook on Environment Statistics, ADB Davide Geneletti 2005. 'Multicriteria analysis to compare the impact of alternative road corridors: a case study in northern Italy' in Impact Assessment and Project Appraisal, Vol. 23, Beech Tree Publishing, pp. 135-146 